\title{
THE PECULIARITIES OF FORMATION AND THERMODYNAMIC FUNCTIONS OF $\tau$-PHASE
}

\author{
N.Yu. Filonenko ${ }^{1 *}$, O. M. Galdina ${ }^{2}$ \\ ${ }^{1}$ State Institution "Dnipropetrovsk Medical Academy of the Ministry of Health of Ukraine*, \\ Dnipro, Ukraine \\ ${ }^{2}$ Oles Honchar Dnipro National University, Dnipro, Ukraine \\ *e-mail: natph2016@gmail.com
}

\begin{abstract}
It is shown that for alloys with boron content of $0.1-6.5 \%$ (wt.) and carbon content of $0.3-4.0 \%$ (wt.) without pretreatment no formation of cubic boron carbide takes place under crystallization. The cubic boron carbide can be obtained by pre-annealing at a temperature of $1173 \mathrm{~K}$ for an hour and further heating to a temperature of $30 \mathrm{~K}$ above the liquidus and cooling of alloys with boron content of $2.5-4.0 \%$ (wt.) and carbon content of $\mathbf{0 . 8}-\mathbf{3 . 0} \%$ (wt.). Formation of crystals of cubic boron carbide is possible as a constituent of multiphase inclusions for alloys with boron content of $0.1-0.3 \%$ (wt.) and carbon content up to $0.4-0.5 \%$ (wt). It should be noted that for alloys with boron content of $4.2-6.0 \%$ (wt.) and carbon content of more than $3.0 \%$ (wt.) the pretreatment does not result in formation of cubic boron carbide. The increase in boron content in the alloy to $0.3-0.5 \%$ (wt.) and carbon content to $0.5-0.7 \%$ (wt.) leads to formation of the eutectic $\alpha-\mathrm{Fe}+\mathrm{Fe}_{23}(\mathrm{CB})_{6}$, which is arranged on the boundaries of pearlite grains.

The thermodynamic functions of $\mathrm{Fe}_{23}(\mathrm{CB})_{6}$ cubic boron carbide are derived for the first time using the Hillert and Staffonsson model and accounting for the first degree approximation of high-temperature expansion of the thermodynamic potential for binary alloys. We obtain temperature dependences of such thermodynamic functions for $\mathrm{Fe}_{23}(\mathrm{CB})_{6}$ phase as Gibbs energy, entropy, enthalpy and heat capacity $C_{P}$, as well as calculate their values at the formation temperature of the phase. The approach used in this paper enables to give the most complete from the thermodynamic point of view description of cubic boron carbide formed from a liquid.
\end{abstract}

Keywords: $\mathrm{Fe}_{23}(\mathrm{CB})_{6}$ cubic boron carbide, Gibbs energy, entropy, enthalpy, heat capacity, fluctuation process.

Received 06.11.2018; Received in revised form 9.12.2018; Accepted 21.12.2018

\section{Introduction}

The study of the physical properties and thermodynamic functions of boron-bearing alloys is of theoretical and practical significance, because borides and boron carbide are formed not only in boron-bearing metal-based alloys, but also in a process of saturation of the surface of alloy with boron and have an effect on the physical properties of borated layer [12]. As well, it would enable to develop metal alloys containing borides and boron carbide, composite materials and coatings with predictable physical properties and phase composition. It is known that $\tau$-phase $\left(\mathrm{Fe}_{23}(\mathrm{CB})_{6}\right)$ is isomorphic to $\mathrm{Cr}_{23} \mathrm{C}_{6}$ carbide [3] and can be formed at high cooling rates [4-5] or from the liquid state after prior thermal cycling in solid-liquid state for, at least, 5-6 cycles in the temperature range of 1123-1613 K [6-8]. Besides, in the structure of iron-based alloys with boron content of no more than $0.1 \%$ (wt.) the cubic boron carbide is a constituent of multiphase inclusions, which are arranged on the boundaries of austenite grains [9]. In literature there is information on position of $\mathrm{Fe}_{23}(\mathrm{CB})_{6}$ cubic boron carbide on the state diagram of the Fe-B-C system [10] and there are even presented the structural diagrams where the regions of $\mathrm{Fe}_{23}(\mathrm{CB})_{6}$ phase and eutectics containing $\mathrm{Fe}_{23}(\mathrm{CB})_{6}$ phase are outlined $[5,11]$. Besides, the Gibbs energy for an equilibrium state is calculated [11-12], but there is no estimated data on the thermodynamic properties of $\mathrm{Fe}_{23}(\mathrm{CB})_{6}$ with accounting for the fluctuation processes.

The purpose of this study is to determine the mechanism of formation, physical properties and thermodynamic functions of $\mathrm{Fe}_{23}(\mathrm{CB})_{6}$ iron cubic boron carbide. 


\section{Materials and methods}

Investigation was carried out for the specimens with carbon content of $0.3-4.0 \%$ (wt.) and boron content of 0.1-6.5\% (wt.), the rest is iron. For obtaining the Fe-B-C system alloys we used the furnace charge of such composition: carbonyl iron (with iron content of $99.95 \%$ (wt.)), amorphous boron (with boron content of $97.50 \%$ (wt.)), electrode graphite (with carbon content of $99.96 \%$ (wt.)). To prevent the segregation, alloys were made from pre-mixed thoroughly and pressed powder of charge materials. Smelting of specimens was performed in a Taman furnace with graphite heater in alundum crucibles in argon atmosphere. To determine the chemical composition of alloy, chemical and spectral analysis was used [13]. Microhardness was measured by PMT-3 device (according to GOST 9460-76). The phase composition of alloys was determined by X-ray microanalysis by means of JSM-6490 microscope, as well as by means of optical microscope "Neophot-21". Local X-ray analysis was carried out using internal standards. The main results were obtained with an electron microscope JSM-6490 with ASID-4D scanning head and "Link Systems 860" software energy-dispersive X-ray microanalyser. The X-ray diffraction analysis was performed with DRON-3 diffractometer in monochromated $\mathrm{Fe}-\mathrm{K}_{\alpha}$ radiation. Sizes of coherent scattering blocks, density of dislocations and microstresses in cubic boron carbide were estimated by means of approximation method [14].

\section{Results and discussion}

The microstructure of alloys with boron content of $2.0-4.5 \%$ (wt.) and carbon content of $1.0-4.0 \%$ (wt.) consists of primary crystals of $\mathrm{Fe}_{3}(\mathrm{CB})$ boron cementite and lamellar eutectics $\gamma-\mathrm{Fe}+\mathrm{Fe}_{3}(\mathrm{CB})$ (Fig. 1, a).

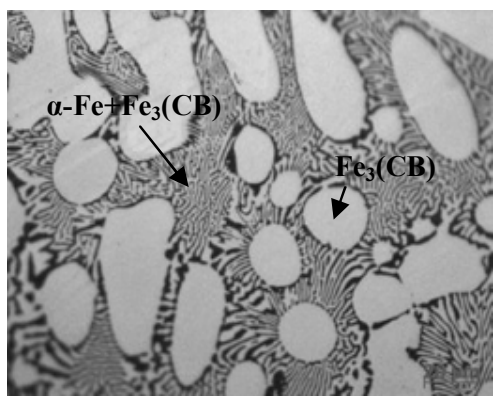

a

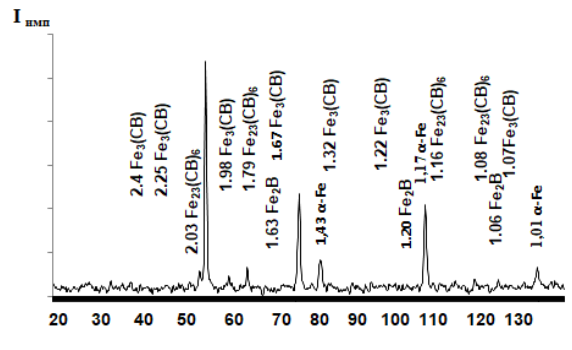

$\mathrm{b}$

Fig. 1. Microstructure $(\mathrm{a}, \times 500)$ and diffractogram (b) of Fe-B-C alloy with boron content of $2.95 \%$ (wt.), carbon content of $2.3 \%$ (wt.).

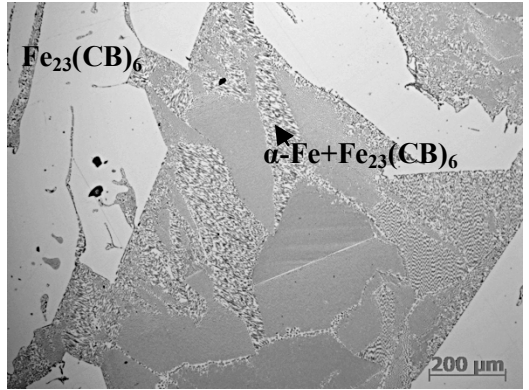

a

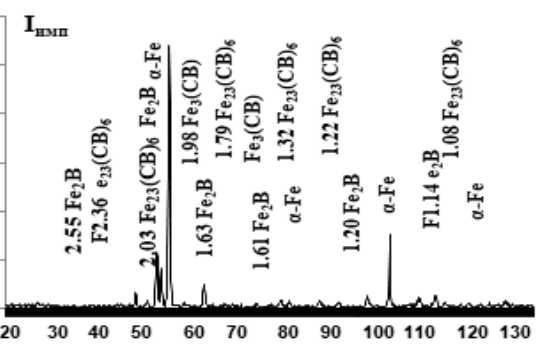

b

Fig. 2. Microstructure $(a, \times 500)$ and diffractogram (b) of Fe-B-C alloy with boron content of $2.95 \%$ (wt.), carbon content of $2.3 \%$ (wt.) after pre-annealing. 
The results of X-ray diffraction analysis of alloy show attendance of $\mathrm{Fe}_{23}(\mathrm{CB})_{6}$ cubic boron carbide line on diffractogram, but this phase is not observed in the microstructure (Fig. 1). Fig. 2, a shows the microstructure of alloy pre-annealed after melting at $1173 \mathrm{~K}$ for an hour and then heated to a temperature of $30 \mathrm{~K}$ above the liquidus and cooled to a room temperature with a rate of $10-100 \mathrm{~K} / \mathrm{s}$. The choice of pre-annealing temperature coincides with the temperature given in $[7,12]$ as the phase formation temperature of $\mathrm{Fe}_{23}(\mathrm{CB})_{6}$. As a result of the pretreatment, in the structure of the alloy $\mathrm{Fe}_{2} \mathrm{~B}$ primary borides, $\mathrm{Fe}_{23}(\mathrm{CB})_{6}$ phase and dispersed eutectics $\alpha$-Fe+Fe ${ }_{23}(\mathrm{CB})_{6}$ with a rod morphology were revealed (Fig. 2). The cubic boron carbide has a skeletal structure, and separate crystals of cubic boron carbide reach 150 microns. According to analysis findings, it is found that formation of $\mathrm{Fe}_{23}(\mathrm{CB})_{6}$ phase occurs at the temperature of $1400-1410 \mathrm{~K}$.

According to results of X-ray analysis the lattice parameter of cubic boron carbide is $10.6387 \AA ; 10.64 \AA$ as follows from [6]; $10.61 \AA$ as results of [15], $10.599 \AA$ from [16].

The carbon content in alloy affects the physical characteristics (Table 1).

Table 1

Crystallite size, microstress degree, and density of dislocations in $\mathrm{Fe}_{23}(\mathrm{CB})_{6}$ phase

\begin{tabular}{|c|c|c|c|c|c|}
\hline \multicolumn{2}{|c|}{ Content in alloy, \% (wt.) } & $\begin{array}{c}\text { Crystallite size } \\
\text { L, } \AA\end{array}$ & $\begin{array}{c}\text { Microstress } \\
\text { degree }\end{array}$ & $\begin{array}{c}\text { Density of } \\
\text { dislocations, } \\
\rho \times 10^{10}, \mathrm{~cm}^{-2}\end{array}$ & $\begin{array}{c}\text { Microhardness } \mathrm{H} \mu, \\
10^{9} \mathrm{~Pa}\end{array}$ \\
\hline 3.2 & 1.4 & 565 & $5.54 \cdot 10^{-3}$ & 9.654 & $6.48 \pm 0,012$ \\
\hline 3.2 & 2.4 & 631 & $4.74 \cdot 10^{-3}$ & 9.972 & $7.3 \pm 0,014$ \\
\hline 3.3 & 2.8 & 702 & $6.53 \cdot 10^{-3}$ & 10.456 & $7.65 \pm 0,011$ \\
\hline 3.5 & 3.0 & 752 & $7.91 \cdot 10^{-3}$ & 11.24 & $7.51 \pm 0,013$ \\
\hline
\end{tabular}

Analysis of the obtained results enables to assume that substitution of boron atoms by carbon atoms in the crystal lattice of $\mathrm{Fe}_{23}(\mathrm{CB})_{6}$ cubic boron carbide is possible and affects the physical characteristics of the phase.

As-cast investigation of the microstructure of alloy with boron content of $4.0 \%$ (wt.), carbon content of $0.9 \%$ (wt.) showed that the primary phase is $\mathrm{Fe}_{2} \mathrm{~B}$ boride. Besides, two eutectics were present in the specimens: $\gamma-\mathrm{Fe}+\mathrm{Fe}_{2} \mathrm{~B}$ and $\gamma-\mathrm{Fe}+\mathrm{Fe}_{3}(\mathrm{CB})$. The boride eutectics $\gamma-\mathrm{Fe}+\mathrm{Fe}_{2} \mathrm{~B}$ succeeded to the shape of $\mathrm{Fe}_{2} \mathrm{~B}$ boride growth and boron cementite eutectics $\gamma-\mathrm{Fe}+\mathrm{Fe}_{3}(\mathrm{CB})$ was presented as curved plates. According to the results of differential thermal analysis, formation of $\mathrm{Fe}_{2} \mathrm{~B}$ boride primary crystals occurs at the temperature of $1452 \mathrm{~K}$. Formation of boride eutectics takes place at $1425 \mathrm{~K}$, and formation of the eutectics $\gamma-\mathrm{Fe}+\mathrm{Fe}_{3}(\mathrm{CB})$ starts at the temperature of $1420 \mathrm{~K}$. At the temperature of $993 \mathrm{~K}$ the polymorphic transformation $\gamma-\mathrm{Fe} \leftrightarrow \alpha-\mathrm{Fe}$ occurs (Fig. 3). The primary crystals in alloy with boron content of $4.0 \%$ (wt.), carbon content of $1.2 \%$ (wt.) after pretreatment are $\mathrm{Fe}_{2} \mathrm{~B}$ phase crystals, on the surface of which boride eutectics $\gamma$ $\mathrm{Fe}+\mathrm{Fe}_{2} \mathrm{~B}$ surrounded by $\mathrm{Fe}_{23}(\mathrm{CB})_{6}+\gamma$-Fe eutectics is formed.

For alloys with boron content of 2.8-3.0\% (wt.) and 2.0-2.2\% (wt.) without pretreatment the formation of cubic boron carbide occurs during crystallization.

Note that for the specimens with boron content of 4.2-6.0\% (wt.) and carbon content of more than $3.0 \%$ (wt.) the annealing at $1173 \mathrm{~K}$ and further heating and cooling do not lead to formation of cubic boron carbide.

The obtained results indicate that formation of cubic boron carbide is possible in the concentration range at boron content of $2.5-4.0 \%$ and carbon content of $0.8-3.0 \%$ (wt.).

At boron content of $0.1-0.3 \%$ (wt.) and carbon content up to $0.4-0.5 \%$ formation of cubic boron carbide as constituent of multiphase inclusions is observed on the boundaries of pearlite grains [9]. 


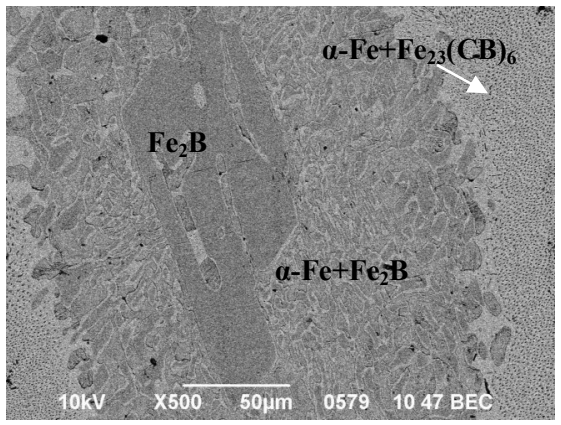

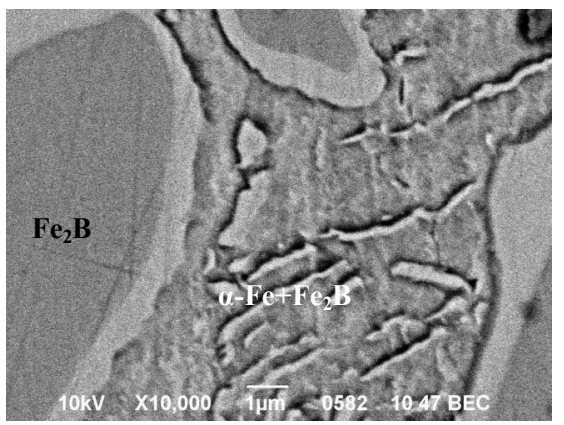

$\mathrm{b}$

Fig. 3. Secondary electron microstructure of the Fe-B-C alloy with boron content of $4.0 \%$, carbon content of $0.9 \%$ (wt.) after pre-annealing.

For alloys with boron content of $0.3-0.5 \%$ (wt.) and carbon content of $0.5-0.7 \%$ (wt.), no formation of separate crystals of cubic boron carbide occurs. The microstructure of alloy consists of pearlite and eutectics $\alpha-\mathrm{Fe}+\mathrm{Fe}_{23}(\mathrm{CB})_{6}$ (Fig. 4). The eutectics $\alpha$ $\mathrm{Fe}+\mathrm{Fe}_{23}(\mathrm{CB})_{6}$ is arranged on the boundaries of pearlite grains.

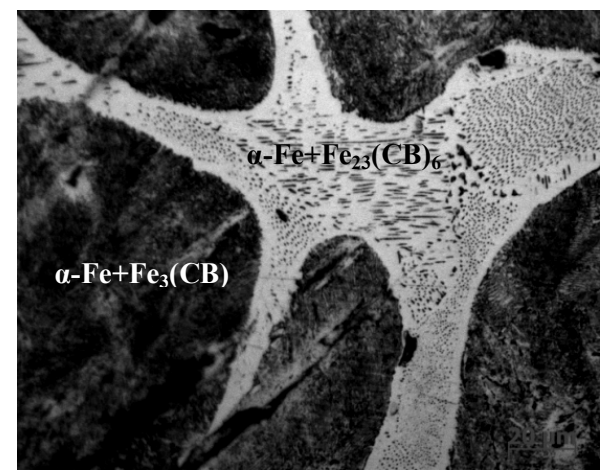

Fig. 4. Microstructure $(a, \times 500)$ and diffractogram $(b)$ of Fe-B-C alloy with boron content of $0.3 \%$, carbon content of $0.5 \%$ (wt.)

One of the key factors affecting the phase formation and phase transformations are thermodynamic functions of the phase. Obtaining of the values of thermodynamic functions for $\mathrm{Fe}_{23}(\mathrm{CB})_{6}$ cubic boron carbide from the experimental data run into certain difficulties. So, accounting in this paper for the fluctuation processes made it possible to determine theoretically the thermodynamic functions of $\mathrm{Fe}_{23}(\mathrm{CB})_{6}$ cubic boron carbide.

Let us denote mole fraction of a component in alloy as $x_{i}$. In Fe-B-C

system the number of components equals $i=3$. For mole fraction of the components in a compound, the condition is fulfilled:

$$
\sum_{i=1}^{3} x_{i}=1
$$

The Gibbs energy of cubic boron carbide $\mathrm{Fe}_{23}(\mathrm{CB})_{6}$ is defined as

$$
G_{\mathrm{m}}^{\mathrm{Fe}_{23}(\mathrm{CB})_{6}}=\sum_{i=1}^{3} x_{i} G_{i}^{0}+R T \sum_{i=1}^{3} x_{i} \ln x_{i}+\frac{1}{2} \sum_{i} \sum_{i \neq \mathrm{j}} x_{i} x_{j} L_{i j}-\frac{1}{2} \sum_{i} \sum_{i \neq \mathrm{j}} \frac{L_{i j}^{2} x_{i}^{2} x_{j}^{2}}{2 Z T R},
$$

where $G_{i}^{0}$ is the Gibbs energy of pure components $(\mathrm{J} / \mathrm{mol}), R$ is universal gas constant $(R=8.31 \mathrm{~J} /(\mathrm{mol} \cdot \mathrm{K})), T$ is temperature $(\mathrm{K}), L_{i j}$ is the energy of interaction between the components $(\mathrm{J} / \mathrm{mol}), Z$ is a coordination number, that for cubic boron carbide equals $Z=116$ [17]. The sum is evaluated for all $i$ and $j$ on the assumption that $i \neq j$. 
It should be noted that the mixing energy depends on the temperature as follows: for the interaction of the first and the second elements it is $L_{12}=a+b T+c T \ln T$, for the second and the third ones $L_{23}=d+e T+f T \ln T$, and for the first and the third $L_{13}=k+l T+m T \ln T$, respectively.

To calculate the Gibbs energy of $\mathrm{Fe}_{23}(\mathrm{CB})_{6}$ phase, we used values of the energy of pure components and interaction energy from the data [18-22]. The calculations give us the following expression for the Gibbs energy of cubic boron carbide $\mathrm{Fe}_{23}(\mathrm{CB})_{6}$ :

$$
G_{\mathrm{m}}^{\mathrm{Fe}_{23}(\mathrm{CB})_{6}}=-34520.3+6.3 T-10^{5} T^{-1} .
$$

According to the results of [11], the Gibbs energy of $\mathrm{Fe}_{23}(\mathrm{CB})_{6}$ phase is $G_{\mathrm{m}}^{\mathrm{Fe}_{23}(\mathrm{CB})_{6}}=-13500+0.6 T$ and, according to [12], $G_{\mathrm{m}}^{\mathrm{Fe}_{23}(\mathrm{CB})_{6}}=-19276-1.05 T$.

Thus, the obtained temperature dependence of the Gibbs energy for cubic boron carbide $\mathrm{Fe}_{23}(\mathrm{CB})_{6}$ (2) determines its value in the high-temperature region, where this phase is forming from the liquid.

The chemical potential of the boron in cubic boron carbide is calculated as

$$
\begin{aligned}
& \mu_{\mathrm{B}}=\left(\frac{\partial G_{m}^{\mathrm{Fe}_{23}(\mathrm{CB})_{6}}}{\partial x_{\mathrm{B}}}\right)_{T}={ }^{0} G_{\mathrm{B}}+R T\left(\ln x_{\mathrm{B}}+1\right)+x_{\mathrm{Fe}}(c T \ln T+b T+a)+ \\
& +x_{\mathrm{C}}(m T \ln T+l T+k)-\frac{(c T \ln T+b T+a)^{2} x_{\mathrm{B}} x_{\mathrm{Fe}}^{2}}{Z R T}-\frac{(m T \ln T+l T+k)^{2} x_{\mathrm{B}} x_{\mathrm{C}}^{2}}{Z R T} .
\end{aligned}
$$

The temperature dependence of the chemical potential of boron in $\mathrm{Fe}_{23}(\mathrm{CB})_{6}$ is

$$
\mu_{\mathrm{B}}=-27231+3.4 T+10^{4} T^{-1} .
$$

The chemical potential of carbon and iron in cubic boron carbide takes the form:

$$
\begin{gathered}
\mu_{\mathrm{C}}=-29566.2+4.7 T+10^{4} T^{-1}, \\
\mu_{\mathrm{Fe}}=-23621+3.1 T+10^{5} T^{-1} .
\end{gathered}
$$

If we compare the values of chemical potentials for boron and for carbon in $\mathrm{Fe}_{23}(\mathrm{CB})_{6}$ phase, we can see that chemical potential of boron is greater than that of carbon. This suggests that in cubic boron carbide $\mathrm{Fe}_{23}(\mathrm{CB})_{6}$ the substitution of boron atoms by carbon atoms is possible, as it was indicated by the authors of [12].

As we know [23], to determine the formation temperature of $\mathrm{Fe}_{23}(\mathrm{CB})_{6}$ phase we have to solve an equation $\partial \mu / \partial y=0$.

The chemical potentials of boron, carbon, and iron in cubic boron carbide take their minimum values, which correspond to the most stable state of this phase:

$$
\frac{\partial \mu_{\mathrm{B}}}{\partial y_{\mathrm{B}}}=\left(\frac{\partial^{2} G_{\mathrm{m}}^{\mathrm{Fe}_{23}(\mathrm{CB})_{6}}}{\partial x_{\mathrm{B}}^{2}}\right)_{T}=0, \frac{\partial \mu_{\mathrm{C}}}{\partial y_{\mathrm{C}}}=\left(\frac{\partial^{2} G_{\mathrm{m}}^{\mathrm{F}_{23}(\mathrm{CB})_{6}}}{\partial x_{\mathrm{C}}^{2}}\right)_{T}=0, \frac{\partial \mu_{\mathrm{Fe}}}{\partial y_{\mathrm{Fe}}}=\left(\frac{\partial^{2} G_{\mathrm{m}}^{\mathrm{Fe}_{23}(\mathrm{CB})_{6}}}{\partial x_{\mathrm{Fe}}^{2}}\right)_{T}=0 .
$$

The solution of equations (3) enables to find the formation temperature of cubic boron carbide $\mathrm{Fe}_{23}(\mathrm{CB})_{6}$, that turns out to be equal to $T=1400.006 \mathrm{~K}$. This is in a good agreement with experimental data.

Let us find entropy, enthalpy and heat capacity $C_{P}$ of cubic boron carbide $\mathrm{Fe}_{23}(\mathrm{CB})_{6}$.

The entropy of $\mathrm{Fe}_{23}(\mathrm{CB})_{6}$ phase is determined as 


$$
\begin{aligned}
& S=-\left(\frac{\partial G}{\partial T}\right)_{x}=-R\left(x_{\mathrm{B}} \ln x_{\mathrm{B}}+x_{\mathrm{Fe}} \ln x_{\mathrm{Fe}}+x_{\mathrm{C}} \ln x_{\mathrm{C}}\right)-x_{\mathrm{B}} x_{\mathrm{Fe}}(c \ln T+b)-x_{\mathrm{C}} x_{\mathrm{Fe}}(f \ln T+e)- \\
& -x_{\mathrm{B}} x_{\mathrm{C}}(m \ln T+l)-\frac{(c T \ln T+b T+a)^{2} x_{\mathrm{B}}^{2} x_{\mathrm{Fe}}^{2}}{2 Z R T^{2}}+\frac{(c T \ln T+b T+a) x_{\mathrm{B}}^{2} x_{\mathrm{Fe}}^{2}(c \ln T+b)}{Z R T}+ \\
& +\frac{(f T \ln T+e T+d) x_{\mathrm{C}}^{2} x_{\mathrm{Fe}}^{2}(f \ln T+e)}{Z R T}-\frac{(f T \ln T+e T+d)^{2} x_{\mathrm{C}}^{2} x_{\mathrm{Fe}}^{2}}{2 Z R T^{2}}+ \\
& +\frac{(m T \ln T+l T+k) x_{\mathrm{B}}^{2} x_{\mathrm{C}}^{2}(m \ln T+l)}{Z R T}-\frac{(m T \ln T+l T+k) x_{\mathrm{B}}^{2} x_{\mathrm{C}}^{2}}{2 Z R T^{2}} .
\end{aligned}
$$

Taking into account the contribution of the first degree approximation in the hightemperature expansion for the thermodynamic potential of binary alloys in the Gibbs energy makes it possible to derive the enthalpy of cubic boron carbide. To calculate the enthalpy of $\mathrm{Fe}_{23}(\mathrm{CB})_{6}$, we use relationship [21]: $\Delta H=\Delta G+T \Delta S$.

The temperature dependence of the enthalpy for this phase is

$$
H^{\mathrm{Fe}_{23}(\mathrm{CB})_{6}}=-37056+5.1 T+10^{5} T^{-1} .
$$

The enthalpy, which corresponds to the formation of $\mathrm{Fe}_{23}(\mathrm{CB})_{6}$ phase is $H_{\mathrm{Fe}_{23}(\mathrm{CB})_{6}}=-29611.59 \mathrm{~J} / \mathrm{mol}$. The enthalpy of the formation of $\mathrm{Fe}_{23} \mathrm{~B}_{6}$ phase is $-11 \mathrm{~kJ} \cdot \mathrm{mol}^{-1} \mathrm{~K}^{-1}$ according to the results of [24] and for $\mathrm{Fe}_{23} \mathrm{C}_{6}$ phase equals $-17.39 \mathrm{~kJ} \cdot \mathrm{mol}^{-1} \mathrm{~K}^{-1}[25]$.

The heat capacity for $\mathrm{Fe}_{23}(\mathrm{CB})_{6}$ phase is calculated as

$$
\begin{aligned}
& C_{p}=T\left(\frac{\partial S}{\partial T}\right)_{p}=\frac{(c \ln T+b)^{2} x_{\mathrm{B}}^{2} x_{\mathrm{Fe}}^{2}}{Z R}-\frac{2(c T \ln T+b T+a) x_{\mathrm{B}}^{2} x_{\mathrm{Fe}}^{2}(c \ln T+b)}{Z R T}+ \\
& +\frac{(c T \ln T+b T+a)^{2} x_{\mathrm{B}}^{2} x_{\mathrm{Fe}}^{2}}{Z R T^{2}}+\frac{(f \ln T+e)^{2} x_{\mathrm{C}}^{2} x_{\mathrm{Fe}}^{2}}{Z R}-\frac{2(f T \ln T+e T+d) x_{\mathrm{C}}^{2} x_{\mathrm{Fe}}^{2}(f \ln T+e)}{Z R T}+ \\
& +\frac{(f T \ln T+e T+d)^{2} x_{\mathrm{C}}^{2} x_{\mathrm{Fe}}^{2}}{Z R T^{2}}+\frac{(m \ln T+l)^{2} x_{\mathrm{B}}^{2} x_{\mathrm{C}}^{2}}{Z R}-\frac{2(m T \ln T+l T+k) x_{\mathrm{B}}^{2} x_{\mathrm{C}}^{2}(m \ln T+l)}{Z R T}+ \\
& +\frac{(m T \ln T+l T+k)^{2} x_{\mathrm{B}}^{2} x_{\mathrm{C}}^{2}}{Z R T^{2}} .
\end{aligned}
$$

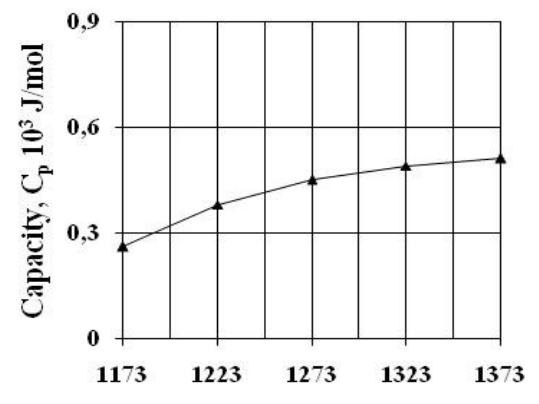

Temper ature, $\mathbf{K}$

Fig. 5. Temperature dependence of heat capacity $C_{P}$ of cubic boron carbide $\mathrm{Fe}_{23}(\mathrm{CB})_{6}$. 
Analysis of the results leads to the conclusion that accounting for the first degree approximation in the high-temperature expansion of the thermodynamic potential makes it possible to obtain the thermodynamic quantities such as entropy, enthalpy, heat capacity, and their temperature dependences for cubic boron carbide $\mathrm{Fe}_{23}(\mathrm{CB})_{6}$. Besides, it gives an opportunity to describe the cubic boron carbide $\mathrm{Fe}_{23}(\mathrm{CB})_{6}$ formed from a liquid in the most complete way from the thermodynamic point of view.

\section{Conclusions}

To obtain cubic boron carbide of iron $\mathrm{Fe}_{23}(\mathrm{CB})$ in $\mathrm{Fe}-\mathrm{B}-\mathrm{C}$ alloys with carbon content of $0.3-4.0 \%$ (wt.) and boron content of $0.1-6.5 \%$ (wt.), the rest is iron, one should perform pretreatment of alloy, such as annealing at $1173 \mathrm{~K}$, further heating to a temperature of $30 \mathrm{~K}$ above the liquidus and then cooling with a rate of $10-100 \mathrm{~K} / \mathrm{s}$ to a room temperature. At boron content of 4.2-6.0\% (wt.) and carbon content of more than $3.0 \%$ there no formation of cubic boron carbide occurs after pretreatment.

It is shown that for alloys with boron content of $2.8-3.0 \%$ (wt.) and $2.0-2.2 \%$ (wt.) without pretreatment the formation of cubic boron carbide $\mathrm{Fe}_{23}(\mathrm{CB})_{6}$ takes place under crystallization. For the first time we obtain temperature dependences of entropy, enthalpy and heat capacity for cubic boron carbide $\mathrm{Fe}_{23}(\mathrm{CB})_{6}$ using the model with accounting for the first degree approximation of high-temperature expansion of the thermodynamic potential. The temperature of formation of $\mathrm{Fe}_{23}(\mathrm{CB})_{6}$ phase is calculated.

The obtained results are important and actual, because they allow to perform calculations of three-component phases taking into account fluctuation processes. In prospect, the thermodynamic functions of multicomponent phases will be studied, which would enable to explain the mechanisms of their formation and phase transformations occurring in multicomponent systems.

\section{References}

1. Goldshteyn, Ya.E. Modifitsirovanie i mikrolegirovanie chuguna i stali / Ya.E. Goldshteyn, V.G. Mizin. - Moscow: Metallurgiya, 1986. - 270 p.

2. Samsonov, G.V. Fizicheskoie materialovedenie karbidov / G.V. Samsonov, G.Sh. Upadhaya, V.S. Neshpor. - Kiev: Naukova dumka, 1974. - 456 p.

3. Lucco Borlera, V. Equlibri allo stato solido nel sistema ferro-boro-carbonio / V. Lucco Borlera, G. Pradelli // La metallurgia itallana. - 1967. - Vol. 11. - P. 907 - 914.

4. Fomichev, O.I. Oblast stabilnosti troinoy fazy $\tau$ v sisteme Fe-B-C / O.I. Fomichev, V.F. Katkov // Izv. Vuz. Chernaya metallurgiya. - 1988. - №1 . - P. 101 103.

5. Spiridonova, I.M. Fazovyi sostav bystrookhlazhdennykh splavov sistemy Fe-BC / I.M. Spiridonova, E.V. Sukhovaya, S.B. Pilyaeva // Visnyk Dnipropetrovskoho universytetu. Seriya Fizyka. Radioelectronika. - 1993. - Issue 5. - P. 33 - 38.

6. Pilyaeva, S.B. Osobennosti obrazovaniya soiedineniya $\mathrm{Fe}_{23}(\mathrm{CB})_{6}$ v splavakh $\mathrm{Fe}-\mathrm{B}-$ C / S.B. Pilyaeva, O.G. Bezrukavaya, V.F. Butenko // Visnyk Dnipropetrovskoho universytetu. Seriya Fizyka. Radioelectronika. - 1998. - Issue 4. - P. 23 - 26 (in Russian).

7. Pilyaeva, S.B. Investigation of pecularities of the structure formation for Fe-B-C system alloys in crystallization / S.B. Pilyaeva, N.Yu. Filonenko // Visnyk Kharkivskoho natsionalnoho universytetu imeni V.N. Karazina, seriya "Fizyka". - 2014. - Issue 21, №1135. - P. 49 - 51.

8. Spiridonova, I.M. Znosostiyki tverdi splavy ta pokryttya na zalizniy osnovi / I.M. Spiridonova // Visnyk Dnipropetrovskoho universytetu. Seriya Fizyka. Radioelectronika. - 2008. - Vol. 16, Issue 15, No. 2. - P. 97 - 105. 
9. Bereza, O.Yu. Doslidzhennia vplyvu enerhiyi zviazku na utvorennia bormistiachykh faz u splavakh systemy Fe-B-C / O.Yu. Bereza, N.Yu. Filonenko and O.S. Baskevych // Fiz. Khim. Tverd. Tila. -2012. - Vol. 13. - P. 968 - 973.

10. Kuzma, Yu.B. Dvoinyie i troynyie sistemy, soderzhashchiye bor: Spravochnik / Yu.B. Kuzma, P.F. Chaban. - M.: Metallurgiya, 1990. -320 p.

11. Ohtani, H. Calculation of Fe-C-B Ternary Phase Diagram / H. Ohtani, M. Hasebe, T. Nishizawa // Transactions ISIJ. - 1988. -Vol. 28. - P. $1043-1050$.

12. Filonenko, N.Yu. . Study of thermodynamic functions of boron-bearing phases for Fe-B-C system / N.Yu. Filonenko // Phys. and chemistry of solids. - 2011. - Vol. 12, № 2. - P. $370-374$.

13. Tverdokhlebova, S.V. Spektrometriya borsoderzhashchikh splavov / S.V. Tverdokhlebova // Visnyk Dnipropetrovskogo universitetu. Seriya Fizika. Radioelektronika. - 2007. - Vol. 14, No. 12/1. - P. 100 - 104.

14. Gorelik, S.S. Rentgenograficheskiy i elektronnoopticheskiy analiz / S.S. Gorelik, Yu.A. Skakov, L.N. Rastorguev. - M.: MISIS, 1994. - 328 p.

15. Fomichev, O.I. Fazovyi sostav splavov Fe-B-C / O.I. Fomichev, V.F. Katkov, A.K. Kushnareva // Neorganicheskiye materialy. - 1976. - Vol. 12, № 1. - P. 128 - 130.

16. Mamonova, A.A. Osobennosti fazovogo sostava i tonkoy struktury boridnykh sloyov spechennykh poroshkovykh staley / A.A. Mamonova // Resursozberihayuchi tekhnolohiyi vyrobnytstva ta obrobky tyskom materialiv u mashynobuduvanni: Zbirnyk naukovykh prats. - Luhansk, 2012. - № 1. - P. 124 - 133.

17. Kuzma, Yu.B. Kristallokhimiya boridov / Yu.B. Kuzma. - Kyiv: Vyshcha shkola, 1983. $-159 \mathrm{p}$.

18. Roble, R.A. Thermodynamic Properties of Minerals and Related Substances at $298.15^{\circ} \mathrm{K}\left(25.0^{\circ} \mathrm{C}\right)$ and One Atmosphere $(1.013$ Bars $)$ Pressure and at Higher Temperatures / R.A. Roble, D.R. Waldbaum. - Orton memorial library the OHIO State University 155 S. Oval Drive, 1970. -262 p.

19. Dinsdale, A.T. SGTE data for pure elements / A.T. Dinsdale // NPL Materials Centre, Division of Industry and Innovation, National Physical Laboratory, Teddington, Middlesex, TW11 0LW, UK. - 1991. - 174 p.

20. Van Rompaey, T. Thermodynamic optimization of the B-Fe system / T. Van Rompaey, K.C. Kumar, P. Wollants // Journal of Alloys and Compounds. - 2002. - Vol. 334. - P. $173-181$.

21. Halemans, B. Thermodynamic reassessment and calculation of the Fe-B phase diagram / B. Halemans, P. Wollemans, J.R. Roos // Z. Metallkd. - 1994. -Vol. 85, No. 10. - P. $676-682$.

22. Hasebe, M. Thermodynamic analysis of ternary Fe-C-B system / M. Hasebe and T. Nishizawa // J. Jap. Inst. Metals. -1974. - Vol. 38, No. 1. - P. 46 - 54.

23. Bazarov, I.P. Termodinamika / I.P. Bazarov. - Moscow: Vysshaya shkola, 1991.- $376 \mathrm{p}$.

24. Guillermet, A.F. Cohesive properties and vibrational entropy of 3d-transition metal carbides / A.F. Guillermet, G. Grimvall // J. Phys. Chem. Solids. - 1992. -Vol. 53, No. 1. - P. $105-125$.

25. Sandberg, N. Carbon impurity dissolution and migration in bec Fe-Cr: Firstprinciples calculations / N. Sandberg, K.O.E. Henriksson and J. Wallenius // Physical Review B. - 2008. - Vol. 78. - 094110 (7 p.). 